www.nature.com/pcan

\title{
CORRIGENDUM
}

\section{Influence of serum testosterone on urinary continence and sexual activity in patients undergoing radical prostatectomy for clinically localized prostate cancer}

M Gacci, G Corona, A Apolone, M Lanciotti, N Tosi, S Giancane, L Masieri, S Serni, M Maggi and M Carini

Prostate Cancer and Prostatic Diseases (2010) 13, 202; doi:10.1038/pcan.2010.13

Correction to: Prostate Cancer and Prostatic Diseases (2010) 13, 168-172; doi:10.1038/pcan.2010.4

In the above article, published online 9 March 2010 and in this issue, the third author's first initial appeared incorrectly. The name should have been listed as G Apolone. 